\title{
Pleiotropic effects of potassium deficiency in a heterocystous, nitrogen-fixing cyanobacterium, Anabaena torulosa
}

\author{
Anuradha Alahari and Shree K. Apte
}

Author for correspondence: Shree K. Apte. Tel: +91225563060 ext. 2348. Fax: +91225560750 or 5560534.

Cell Biology Division, Bhabha Atomic Research Centre, Trombay, Mumbai 400085, India

\begin{abstract}
Omission of potassium from the growth medium caused multiple metabolic impairments and resulted in cessation of growth of the filamentous, heterocystous, nitrogen-fixing cyanobacterium Anabaena torulosa, during both diazotrophic and nitrogen-supplemented growth. Prominent defects observed during potassium deprivation were: (i) the loss of photosynthetic pigments, (ii) impairment of photosynthetic functions, (iii) reduced synthesis of dinitrogenase reductase (Fe-protein), (iv) inhibition of nitrogenase activity, and (v) specific qualitative modifications of protein synthesis leading to the repression of twelve polypeptides and synthesis and accumulation of nine novel polypeptides. The observed metabolic defects were reversible, and growth arrested under prolonged potassium deficiency was fully restored upon re-addition of potassium. Such pleiotropic effects of potassium deficiency demonstrate that apart from its well-known requirement for $\mathrm{pH}$ and turgor homeostasis, $\mathrm{K}^{+}$plays other vital specific roles in cyanobacterial growth and metabolism.
\end{abstract}

Keywords: potassium deficiency, cyanobacteria, nitrogen fixation, photosynthesis, Anabaena torulosa

\section{INTRODUCTION}

In bacteria, potassium $\left(\mathrm{K}^{+}\right)$is a major cellular cation, with concentrations ranging from $0 \cdot 2$ to $0.6 \mathrm{M}$ (Epstein $\&$ Schultz, 1965). Such high intracellular levels of $\mathrm{K}^{+}$are maintained by the activities of multiple uptake systems (Harold \& Kakinuma, 1986; Altendorf \& Epstein, 1993; Schrempf et al., 1995; Stumpe et al., 1996). $\mathrm{K}^{+}$plays a major role in the maintenance of intracellular $\mathrm{pH}$ (Booth, 1985) and cell turgor (Epstein, 1986; Whatmore \& Reed, 1990; Csonka \& Hanson, 1991) in bacteria. $\mathrm{K}^{+}$ deficiency has been found to decrease protein synthesis (Harold \& Baarda, 1968) and to influence the activity of certain cellular enzymes (Suelter, 1970). More specifically, intracellular $\mathrm{K}^{+}$has been found to positively regulate the expression of certain osmo-responsive genes, such as proU (Prince \& Villarejo, 1990), ots $A$ (Giaever et al., 1988) and others in enteric bacteria. Recently $\mathrm{K}^{+}$has also been implicated in osmoregulatory functions (Meury \& Kohiyama, 1993) and in regulation of heat-shock response (Palleros et al., 1993) in bacteria.

For the last several years our laboratory has been exploring the stress and adaptive responses of photosynthetic nitrogen-fixing Anabaena strains to a variety of environmental conditions ranging from nutrient deficiency (Apte \& Thomas, 1983, 1984) to salinity, osmotic and heat stresses (Apte et al., 1987; Apte \& Bhagwat, 1989; Bhagwat \& Apte, 1989; Fernandes et al., 1993; Iyer et al., 1994). $\mathrm{K}^{+}$plays a vital role in stressful environments, both as an extracellular signal and as an intracellular metabolic regulator. Information on the effects of this cation on cyanobacterial growth and metabolism would, therefore, be of value for a better understanding of the molecular basis of stress tolerances and for agricultural applications of these microbes as biofertilisers in stressful environments.

A requirement of $\mathrm{K}^{+}$has been known for cyanobacteria since the 1940s (see Wolk, 1973). All cyanobacterial culture media include varying amounts of $\mathrm{K}^{+}$, ranging from $0.1 \mathrm{mM}$ in ASM to $5.74 \mathrm{mM}$ in Kratz and Myers medium (Castenholz, 1988). The mechanism of $\mathrm{K}^{+}$ transport (Reed et al., 1981), induction of $\mathrm{K}^{+}$transport by turgor perturbations (Reed \& Stewart, 1985) and accumulation of $\mathrm{K}^{+}$during osmotic adjustments (Miller et al., 1976; Reed et al., 1984, 1985) have been described in cyanobacteria. But apart from these studies, there have to our knowledge been no investigations into the nature of the cyanobacterial requirement for $\mathrm{K}^{+}$. The present work was undertaken to investigate the role played by $\mathrm{K}^{+}$in the cellular physiology of a photo- 
synthetic, nitrogen-fixing Anabaena strain. The results show that, in addition to a possible turgor loss, $\mathrm{K}^{+}$ deprivation causes multiple metabolic impairments, during both nitrogen-supplemented and diazotrophic growth.

\section{METHODS}

Organism and growth conditions. A filamentous, heterocystous, nitrogen-fixing, brackish-water cyanobacterial strain, Anabaena torulosa (Apte \& Thomas, 1980), was used in axenic condition. Stock cultures were maintained in the standard BG-11 medium without combined nitrogen (Castenholz, 1988). The medium was modified to obtain either $\mathrm{BG}-11 / \mathrm{K} 0$ (in which $\mathrm{K}_{2} \mathrm{HPO}_{4}$ was replaced by equimolar $\mathrm{Na}_{2} \mathrm{HPO}_{4}$ ) or BG-11/K5 (BG-11/K0 containing $5 \mathrm{mM} \mathrm{KCl}$ ) media. When required, $3 \mathrm{mM} \mathrm{NH}_{4} \mathrm{Cl}$ and $5 \mathrm{mM}$ MOPS were added to either $\mathrm{BG}-11 / \mathrm{K} 0$ or $\mathrm{BG}-11 / \mathrm{K} 5$ media for combined nitrogen supplementation. The initial $\mathrm{pH}$ of all media was adjusted to $7 \cdot 0$.

$\mathrm{K}^{+}$starvation was achieved by harvesting 3-d-old BG-11/K5grown cells (by centrifugation at $5000 \mathrm{~g}$ for $5 \mathrm{~min}$ ) followed by washing three times, each with 5 vols BG-11/K0 medium. Washed cells were inoculated in BG-11/K0 and BG-11/K5 media at a density of $0 \cdot 6-1 \cdot 0 \mu \mathrm{g}$ chlorophyll $a \mathrm{ml}^{-1}$. All cultures were grown photoautotrophically under continuous illumination $\left(2.5 \mathrm{~mW} \mathrm{~cm}^{-2}\right)$ from white fluorescent tubes and under aeration $\left(21 \mathrm{~min}^{-1}\right)$ at $25 \pm 2{ }^{\circ} \mathrm{C}$.

Measurement of growth and nitrogenase activity. Growth was usually measured in terms of chlorophyll $a$ content as described by Mackinney (1941), or occasionally as turbidity $\left(\mathrm{OD}_{750}\right)$ or total protein content (determined by the Lowry method). Nitrogenase activity was estimated in $2 \mathrm{ml}$ culture aliquots by the standard acetylene reduction assay, as described earlier (Apte et al., 1987). Standard ethylene (Applied Science Laboratories) was used for determination of ethylene in the samples.

Estimation of photosynthetic pigments, photoevolution of oxygen and photofixation of carbon. Relative levels of photosynthetic pigments were estimated from the absorption spectra of dilute suspensions of whole filaments in the visible range $(400-750 \mathrm{~nm})$. The spectra were recorded in a Hitachi 150-20 UV/visible double-beam spectrophotometer, where the turbidity of cultures could be adjusted to zero to obtain spectra from comparable cell densities. $A_{680}, A_{620}$ and $A_{495}$ were taken as in vivo measures of chlorophyll $a$, phycocyanin and carotenoids, respectively, as described earlier (Apte \& Thomas, 1983).

For measurements of photosynthesis, $1.5 \mathrm{ml}$ culture aliquots (5 $\mu \mathrm{g}$ chlorophyll $\mathrm{a} \mathrm{ml}^{-1}$ ) were transferred to an oxygraph chamber (Gilson) maintained with stirring at $25^{\circ} \mathrm{C}$. Samples were illuminated with monochromatic light $(650 \mathrm{~nm}, 500 \mathrm{~W}$ $\mathrm{cm}^{-2}$ ), passing through a heat filter of $1 \mathrm{M} \mathrm{CuSO}_{4}$ solution, to record the $\mathrm{O}_{2}$ evolved. The oxygraph was calibrated by a standard reaction with glucose/glucose oxidase and catalase. Light-dependent uptake of bicarbonate was measured with $1 \mathrm{ml}$ culture aliquots $\left(5 \mu \mathrm{g}\right.$ chlorophyll $\left.a \mathrm{ml}^{-1}\right)$ incubated under white light $\left(2.5 \mathrm{~mW} \mathrm{~cm}^{-2}\right)$ at $25^{\circ} \mathrm{C}$ with $1 \mu \mathrm{Ci}\left(37 \mathrm{kBq} \mathrm{ml}^{-1}\right)$ $\mathrm{NaH}^{14} \mathrm{CO}_{3}$ (specific activity $51 \mathrm{mCi} \mathrm{mmol}^{-1}, 1.89 \mathrm{GBq}$ $\mathrm{mmol}^{-1}$ ) with shaking (150 r.p.m.) for $15 \mathrm{~min}$, as described earlier (Apte \& Thomas, 1983).

Determination of protein synthesis rates. One-millilitre culture aliquots were pulse-labelled with $\left[{ }^{35} \mathrm{~S}\right]$ methionine (specific activity $>30 \mathrm{TBq} \mathrm{mmol}^{-1}$ ) added at $1.5 \mathrm{MBq} \mathrm{ml}^{-1}$, for $5 \mathrm{~min}$. Radiolabelling was terminated by transferring cells to ice followed by rapid centrifugation $(1 \mathrm{~min})$ in a microcentrifuge. Cells were washed three times with BG-11 medium and once with sterilized distilled water. Solubilization and extraction of proteins, and estimation of the radioactivity incorporated into proteins, have been described earlier (Apte \& Bhagwat, 1989).

Protein electrophoresis, Western blotting and immunodetection. Preparation of protein samples and electrophoresis were carried out as described earlier (Apte \& Bhagwat, 1989). Cellular proteins were resolved by electrophoresis on denaturing gradient $(5-14 \%, \mathrm{w} / \mathrm{v}$, acrylamide) SDSpolyacrylamide slab gels. Gels were fixed and stained with Coomassie brilliant blue G-250. Alternatively, proteins were resolved by SDS-PAGE on $10 \%(\mathrm{w} / \mathrm{v})$ gels and transferred to positively charged nylon membranes (Boehringer Mannheim) by electroblotting at $0.2 \mathrm{~A}$ for $16-18 \mathrm{~h}$ in a transfer buffer containing $125 \mathrm{mM}$ Tris $/ \mathrm{HCl} \mathrm{pH} 8.6$ and $192 \mathrm{mM}$ glycine. The blot was washed with buffer 1 [ $50 \mathrm{mM}$ Tris $/ \mathrm{HCl} \mathrm{pH} \mathrm{7.4,}$ $150 \mathrm{mM} \mathrm{NaCl}$ and $1 \%(\mathrm{w} / \mathrm{v}$ ) blocking reagent (casein acid hydrolysate]. It was then incubated with 1:3000 dilution of an anti-dinitrogenase reductase ( $\mathrm{Fe}$-protein) antibody in buffer 1 at $4{ }^{\circ} \mathrm{C}$ for $16-18 \mathrm{~h}$. The antiserum consisted of rabbit IgG raised against a composite mixture of purified Fe-proteins from Rhodospirillum rubrum, Azotobacter vinelandii and Rhizobium japonicum. Immunodetection of the anti-Feprotein antibody was carried out using anti-rabbit IgG conjugated to alkaline phosphatase followed by colour development with nitro blue tetrazolium and 5-bromo-4-chloro3-indolyl phosphate (X-phos) (all obtained from Boehringer Mannheim), according to the manufacturer's recipe.

\section{RESULTS}

In initial experiments the standard BG-11 growth medium, which contains $0 \cdot 175 \mathrm{mM} \mathrm{K}^{+}$, was found to be limited in the availability of this cation. Addition of up

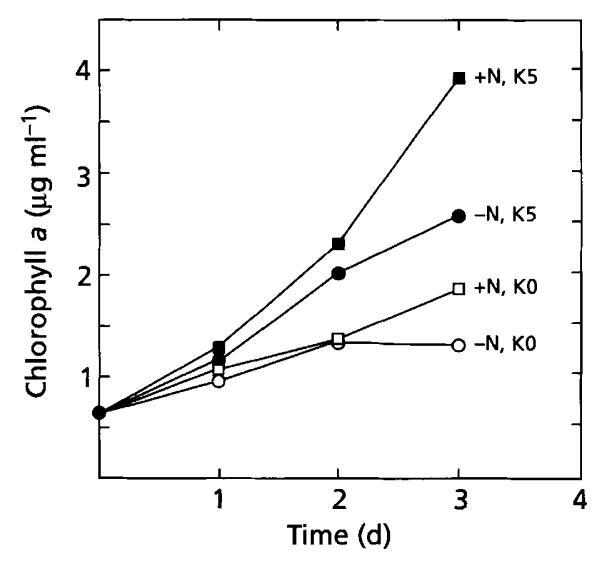

Fig. 1. Effect of $\mathrm{K}^{+}$on the growth of $A$. torulosa in media free of combined nitrogen ( $-\mathrm{N}$, circles) or supplemented with $\mathrm{NH}_{4} \mathrm{Cl}$ ( $+\mathrm{N}$, squares). In both conditions, filaments were grown either in the absence ( $\mathrm{KO}$, open symbols) or presence ( $\mathrm{K} 5$, filled symbols) of $5 \mathrm{mM} \mathrm{KCl}$. Growth was measured as the content of chlorophyll $a$. Each value is the mean of three replicates; variation from the mean was less than $10 \%$. The results are representative of three similar independent experiments. 
Table 1. Pleiotropic effects of $\mathrm{K}^{+}$deficiency in $A$. torulosa

All determinations (except heterocyst frequency) were carried out $3 \mathrm{~d}$ after inoculation in the respective medium. Growth was calculated as increase in chlorophyll $a$ density over that present at the time of inoculation. Numbers in parentheses represent values for $\mathrm{K}^{+}$-deficient cultures expressed as a percentage of the respective $\mathrm{K}^{+}$-supplemented controls.

\begin{tabular}{|c|c|c|c|c|}
\hline & \multicolumn{4}{|c|}{ Growth medium: } \\
\hline & \multicolumn{2}{|c|}{ Plus $\mathbf{N}$} & \multicolumn{2}{|c|}{ Minus $\mathbf{N}$} \\
\hline & BG-11/K5 & BG-11/K0 & BG-11/K5 & BG-11/K0 \\
\hline $\begin{array}{l}\text { Growth }[\mu \mathrm{g} \text { chlorophyll } a(\mathrm{ml} \\
\left.\text { culture })^{-1}\right]\end{array}$ & $3 \cdot 29$ & $1 \cdot 23(37)$ & 1.93 & $0.65(34)$ \\
\hline $\begin{array}{l}\text { Heterocyst frequency ( } \% \text { of total } \\
\text { cells)* }\end{array}$ & - & - & $8 \cdot 80$ & $8 \cdot 45$ \\
\hline $\begin{array}{l}\text { Nitrogenase activity }\left[\mu \mathrm{mol} \mathrm{C}_{2} \mathrm{H}_{2}\right. \\
\left.\text { reduced (mg protein })^{-1} \mathrm{~min}^{-1}\right]\end{array}$ & - & - & $10 \cdot 1$ & $1 \cdot 60(16)$ \\
\hline \multicolumn{5}{|l|}{ Photosynthetic pigments $\uparrow$} \\
\hline Chlorophyll $a\left(A_{680}\right)$ & $0 \cdot 160$ & $0.054(34)$ & $0 \cdot 235$ & $0.075(32)$ \\
\hline Phycocyanin $\left(A_{620}\right)$ & $0 \cdot 135$ & $0 \cdot 044(33)$ & $0 \cdot 190$ & $0 \cdot 060(32)$ \\
\hline Carotenoids $\left(A_{495}\right)$ & $0 \cdot 140$ & $0.060(43)$ & $0 \cdot 210$ & $0 \cdot 149(71)$ \\
\hline \multicolumn{5}{|l|}{ Photosynthetic functions } \\
\hline $\begin{array}{l}\text { Photoevolution of } \mathrm{O}_{2}[\mu \mathrm{mol}(\mathrm{mg} \\
\left.\text { protein })^{-1} \mathrm{~min}^{-1}\right]\end{array}$ & 350 & $193(55)$ & 750 & $263(35)$ \\
\hline $\begin{array}{l}\text { Photofixation of } \mathrm{CO}_{2}\left[10^{-7} \times \text { c.p.m. }\right. \\
\left.\mathrm{NaH}^{14} \mathrm{CO}_{3}(\mathrm{mg} \text { protein })^{-1} \mathrm{~h}^{-1}\right]\end{array}$ & $9 \cdot 50$ & $1 \cdot 61(17)$ & $7 \cdot 40$ & $2 \cdot 44(33)$ \\
\hline $\begin{array}{l}\text { Protein synthesis }\left[10^{-5} \times \text { c.p.m. }\right. \\
\left.\left[{ }^{35} \mathrm{~S}\right] \text { methionine }(\mu \mathrm{g} \text { protein })^{-1} \mathrm{~min}^{-1}\right]\end{array}$ & $\mathrm{ND}$ & ND & $1 \cdot 20$ & $0.78(65)$ \\
\hline
\end{tabular}

ND, Not determined.

*Heterocyst frequency was determined from $>2000$ cells counted under the microscope $30 \mathrm{~h}$ after inoculation.

†Values estimated from absorption spectra of very dilute suspensions of whole filaments.

to $5 \mathrm{mM} \mathrm{K}^{+}$(as $\mathrm{KCl}$ ) to $\mathrm{BG}-11$ enhanced growth (data not shown). Therefore, in all experiments BG-11/K5 served as the $\mathrm{K}^{+}$-supplemented control medium. The residual $\mathrm{K}^{+}$contamination in $\mathrm{BG}-11 / \mathrm{K} 0$ was found to be less than $10 \mu \mathrm{M}$, by atomic absorption spectrometry.

\section{Effect of $\mathrm{K}^{+}$on growth}

Growth was retarded during $\mathrm{K}^{+}$limitation under both nitrogen-deficient and nitrogen-supplemented conditions (Fig. 1). The extent of inhibition caused by $\mathrm{K}^{+}$ starvation in nitrogen-deficient $(34 \%)$ and nitrogensupplemented $(37 \%)$ media was comparable (Table 1$)$. The requirement of $\mathrm{K}^{+}$during nitrogen-fixing (diazotrophic) growth was investigated in detail.

Prolonged starvation of $\mathrm{K}^{+}$did not affect the viability of nitrogen-fixing A. torulosa filaments (Fig. 2). Microscopic examination of $\mathrm{BG} 11 / \mathrm{K} 0$ cultures did not reveal any cell lysis. Addition of $5 \mathrm{mM} \mathrm{KCl}$ to BG-11/K0 cultures, after 2,4 or $6 \mathrm{~d}$ of $\mathrm{K}^{+}$starvation, rapidly revived growth and fully restored it to the level of BG11/K5 cultures. The revival rate was dependent on the extent of previous starvation, i.e. the longer the

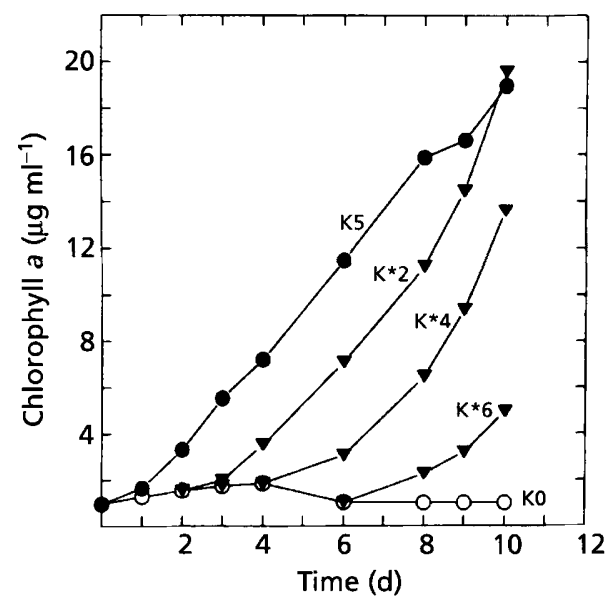

Fig. 2. Revival of growth of $\mathrm{K}^{+}$-starved $A$. torulosa filaments upon re-addition of $\mathrm{K}^{+} . \mathrm{KCl}(5 \mathrm{mM})$ was added $(\nabla)$ to combined nitrogen-free BG-11/KO cells $(O)$ after $2\left(K^{\star} 2\right), 4\left(K^{\star} 4\right)$ and 6 $(K \star 6) \mathrm{d}$ of $\mathrm{K}^{+}$starvation. Growth of cells in combined nitrogenfree $B G-11 / K 5(O)$ is included for comparison. The values are means of three replicates; variation from the mean was less than $10 \%$. The results are representative of three similar independent experiments. 


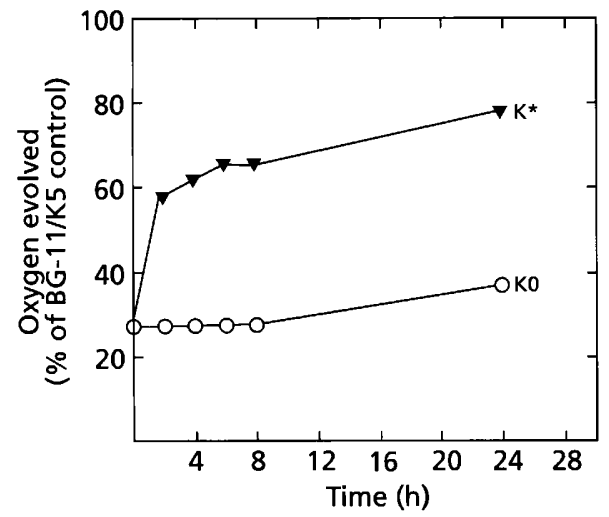

Fig. 3. Effect of $\mathrm{K}^{+}$on the photoevolution of oxygen in nitrogen-fixing $A$. torulosa filaments. Oxygen evolved by the $B G-11 / K O$ cells $(K O, O)$ was compared with that evolved by the BG-11/K0 cells to which $5 \mathrm{mM} \mathrm{KCl}$ was added at $0 \mathrm{~h}\left(\mathrm{~K}^{*}, \nabla\right)$ and expressd as a percentage of the value for BG-11/K5 filaments. Values corresponding to $100 \%$ (BG-11/K5 control) were 945 , $941,941,920,889$ and $750 \mathrm{nmol} \mathrm{O}_{2}$ (mg protein) ${ }^{-1} \mathrm{~min}^{-1}$ at 0,2 , $4,6,8$ and $24 \mathrm{~h}$, respectively. The values represent means of two replicates and the variation from the mean was less than $10 \%$. The results are representative of two similar independent experiments.

starvation, the slower the revival. Results obtained using protein content or turbidity as measures of growth were very similar to those in Figs 1 and 2 (data not shown).

\section{Effects of $\mathrm{K}^{+}$on morphology and differentiation}

Cells of $A$. torulosa were distinctly smaller under $\mathrm{K}^{+}$ deficiency, although the length of the filaments, and the number, frequency and morphology of the heterocysts, were unaffected (Table 1). In both the $\mathrm{K}^{+}$-deficient and the $\mathrm{K}^{+}$-supplemented filaments, heterocyst differentiation reached a peak around $30 \mathrm{~h}(8-9 \%$ heterocysts as compared to $4 \%$ at inoculation) (Table 1 ). The heterocysts appeared normal and, like those formed under $\mathrm{K}^{+}$-sufficient conditions, they lacked the red fluorescence of phycobiliproteins typical of the vegetative cells. The inhibition of diazotrophic growth by $\mathrm{K}^{+}$starvation was therefore apparently not due to any defects in the development of or the quality of the heterocysts.

\section{Effects of $\mathrm{K}^{+}$on photosynthesis}

$\mathrm{K}^{+}$deficiency lowered the content of all major photosynthetic pigments, viz. chlorophyll $a$, phycocyanin and carotenoids, and inhibited the photoevolution of oxygen as well as the photofixation of carbon, both in the presence and in the absence of combined nitrogen in the growth medium (Table 1). In nitrogen-fixing cultures, the photoevolution of oxygen partially recovered (to about $65 \%$ of the controls) within $2-4$ h upon addition of $5 \mathrm{mM} \mathrm{KCl}$ to $\mathrm{K}^{+}$-deficient cells (Fig. 3). However, subsequent recovery of photosynthetic oxygen evolution and carbon fixation was slow $(75-80 \%$ in $24 \mathrm{~h}$; Fig. 3$)$;

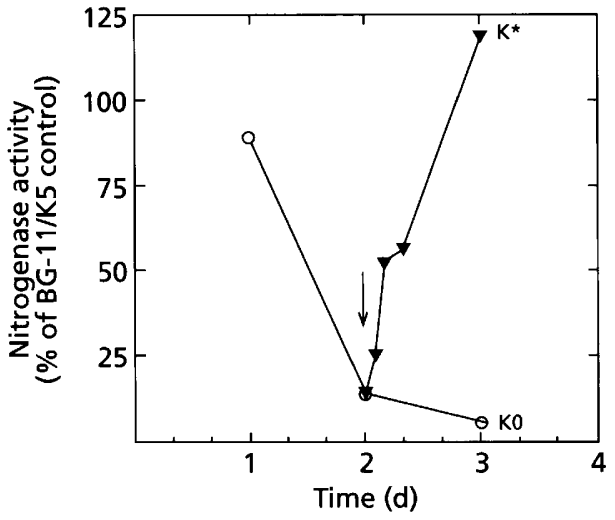

Fig. 4. Effect of $\mathrm{K}^{+}$on nitrogenase activity in $A$. torulosa. Nitrogenase activity of BG-11/K0 cells $(\mathrm{KO}, \mathrm{O})$ was compared with that of BG-11/KO cells to which $5 \mathrm{mM} \mathrm{KCl}$ was added at the time indicated by the arrow $\left(K^{*}, \nabla\right)$ and expressed as a percentage of the value for BG-11/K5 filaments. Values corresponding to $100 \%$ (BG-11/K5 control) on days 1,2 and 3 were $8.7,11.3$ and $9.5 \mu \mathrm{mol}$ ethylene $\left(\mathrm{mg}\right.$ chlorophyll a) ${ }^{-1} \mathrm{~h}^{-1}$, respectively. The $100 \%$ (BG-11/K5 control) values corresponding to the activity of the $K^{*}$ culture at 2,4 and $8 \mathrm{~h}$ after addition of $\mathrm{K}^{+}$(shown by the arrow) were 11.4. 11.8 and $10.8 \mu \mathrm{mol}(\mathrm{mg}$ chlorophyll $a)^{-1} h^{-1}$, respectively. Values are means of three replicates and the variation from the mean was less than $10 \%$. The results are representative of four independent experiments.

complete $(100 \%)$ recovery occurred only after $3-4 \mathrm{~d}$ (data not shown).

\section{Effects of $\mathrm{K}^{+}$on nitrogen fixation}

Nitrogenase activity in $A$. torulosa was severely inhibited by $\mathrm{K}^{+}$deficiency (Fig. 4). Two days of $\mathrm{K}^{+}$ starvation reduced the activity to only $15-20 \%$ of that in $\mathrm{K}^{+}$-sufficient cells and by day 3 the activity was negligible. Addition of $\mathrm{K}^{+}$to BG-11/K0 cultures, at the time indicated by the arrow in Fig. 4, restored nitrogenase activity in a time-dependent manner: $60 \%$ recovery within $8 \mathrm{~h}$ and $>100 \%$ recovery within $24 \mathrm{~h}$ (Fig. 4). A similar experiment conducted $3 \mathrm{~d}$ after initiation of $\mathrm{K}^{+}$starvation also showed revival of nitrogenase activity, albeit at a slower rate (data not shown).

Western blotting of protein extracts and immunodetection of dinitrogenase reductase (Fe-protein of nitrogenase complex) identified a single $33 \mathrm{kDa}$ polypeptide whose levels were considerably reduced after $48-72 \mathrm{~h}$ of $\mathrm{K}^{+}$starvation (Fig. 5). Addition of $5 \mathrm{mM} \mathrm{KCl}$ caused no significant increase in the Fe-protein content in $8 \mathrm{~h}$ (Fig. 5, lane 4), although within this time the nitrogenase activity recovered to $60 \%$ of the control (Fig. 4). This can be ascribed to a comparable recovery of photosynthesis (Fig. 3) and consequent increased availability of reductant, ATP and carbon skeletons. On the other hand, $24 \mathrm{~h}$ after addition of $\mathrm{K}^{+}$the level of $\mathrm{Fe}$ protein (Fig. 5, lane 7) far exceeded the observed nitrogenase activity (Fig. 4). This may be due to limitations on the availability of reductant and ATP for 


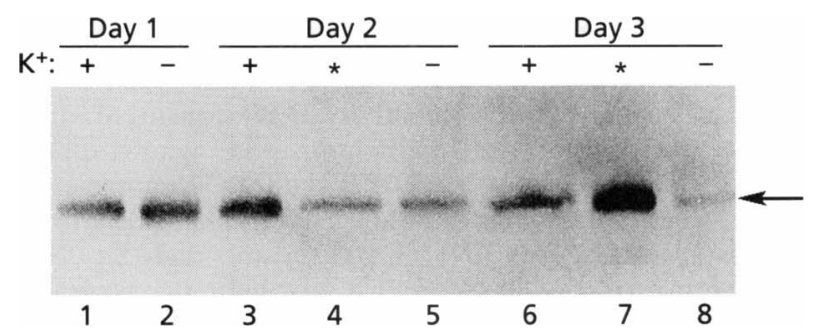

Fig. 5. Effect of $\mathrm{K}^{+}$on the content of dinitrogenase reductase (Fe-protein of nitrogenase complex) in A. torulosa. Solubilized protein extracts containing $150 \mu \mathrm{g}$ protein were resolved by SDS-PAGE on $10 \%(\mathrm{w} / \mathrm{v})$ gels and electroblotted onto nylon membranes. The $33 \mathrm{kDa}$ polypeptide (arrowed) was immunodetected using a primary anti-dinitrogenase reductase (rabbit IgG) antibody followed by a secondary anti-rabbit IgG coupled to alkaline phosphatase. The + and - respectively denote the presence (BG-11/K5) or the absence (BG-11/K0) of $5 \mathrm{mM} \mathrm{KCl}$ in the growth medium; the * indicates addition of $5 \mathrm{mM} \mathrm{KCl}$ to BG-11/K0-grown cells on day 2 . Samples in lanes 4 and 7 were taken 8 and $24 \mathrm{~h}$, respectively, after addition of $\mathrm{K}^{+}$.

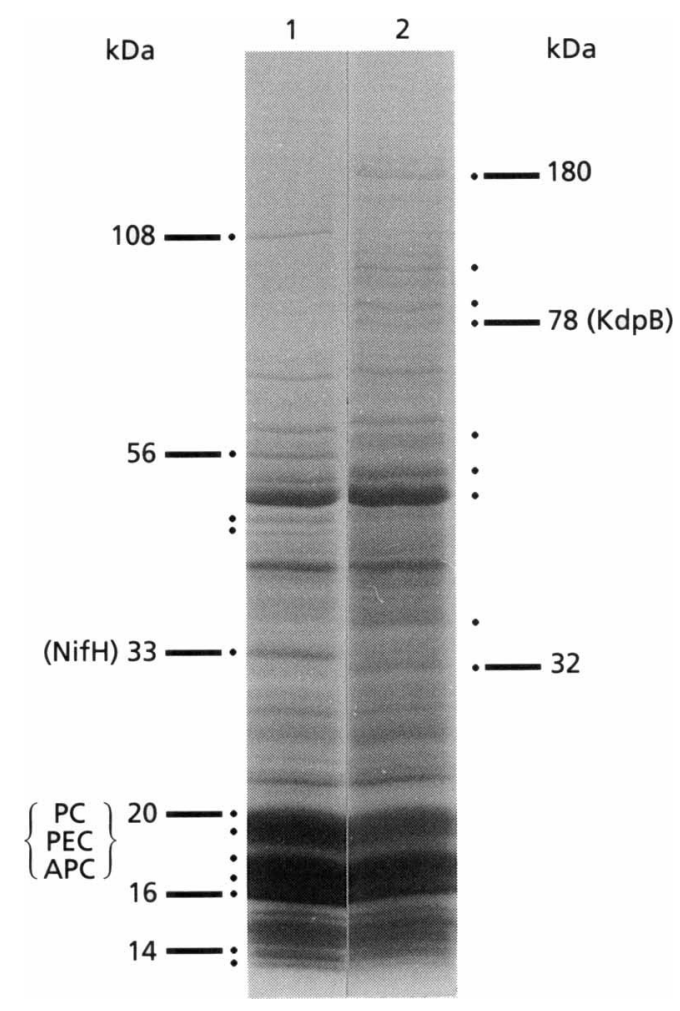

Fig. 6. Modification of protein synthesis in $A$. torulosa during $\mathrm{K}^{+}$starvation. Protein samples $(100 \mu \mathrm{g})$, from cells grown in BG11/K5 (lane 1) or BG-11/KO (lane 2) for $3 \mathrm{~d}$ were resolved by SDS-PAGE on a $5-14 \%(\mathrm{w} / \mathrm{v})$ gradient gel and visualized by Coomassie staining. Prominent polypeptides whose levels were either decreased $(13.5,14.0,16.0,17.0,18.0,19.5,20.0,33.0$ $48.0,50.0,56.0$ and $108.0 \mathrm{kDa}$ species) or enhanced $(32.0,36.0$, $52.0,54.0,58 \cdot 0,78 \cdot 0,82.0,90.0$ and $180.0 \mathrm{kDa}$ species) by $\mathrm{K}^{+}$ starvation are marked with dots on the left and the right, respectively. The numbers indicate the molecular masses determined using standard proteins (SDS-6H and SDS-7 kits from Sigma) that were co-electrophoresed on the gel. Some of the identified proteins are given in parentheses. PC, phycocyanin; PEC, phycoerythrocyanin; APC, allophycocyanin. nitrogen fixation, since such cultures exhibited only partial recovery of photosynthesis (Fig. 3).

\section{Effects of $\mathrm{K}^{+}$on protein synthesis}

$\mathrm{K}^{+}$starvation decreased the efficiency of cyanobacterial protein synthesis. Under nitrogen-fixing conditions, the rate of $\left[{ }^{35} \mathrm{~S}\right]$ methionine incorporation into proteins was reduced by $35 \%$ after $3 \mathrm{~d}$ of $\mathrm{K}^{+}$starvation (Table 1 ). After 5 and $7 \mathrm{~d}$ of $\mathrm{K}^{+}$starvation, the rate of protein synthesis decreased by $54 \%$ and $68 \%$ respectively (data not shown). In addition, the proteins synthesized under $\mathrm{K}^{+}$deprivation appeared to be markedly different from those synthesized by $\mathrm{K}^{+}$-supplemented cells (Fig. 6). Synthesis of 12 polypeptides was adversely affected and their levels declined after $3 \mathrm{~d}$ of $\mathrm{K}^{+}$starvation. One of the repressed proteins $(33 \mathrm{kDa})$ was identified as dinitrogenase reductase (NifH) (Fig. 5). The five most abundant Anabaena polypeptides (16-20 kDa) (Fig. 6) appeared as bluish-grey bands on gels even without staining. These have earlier been shown to belong to the $\alpha / \beta$-subunits of phycocyanin, allophycocyanin and phycoerythocyanin, which together constitute the phycobilisomes of Anabaena (Wood \& Haselkorn, 1980). The levels of these polypeptides decreased under $\mathrm{K}^{+}$starvation (Fig. 6), in agreement with the loss of phycocyanin and photosynthetic functions shown in Table 1 . The synthesis of at least nine polypeptides was selectively enhanced and these accumulated in $\mathrm{K}^{+}$starved filaments. A $78 \mathrm{kDa}$ polypeptide (earlier reported as $90 \mathrm{kDa}$, due to a miscalculation) was previously shown to cross-react with an antibody against the $\mathrm{KdpB}$ protein of the $\mathrm{K}^{+}$-dependent ATPase of Escherichia coli (Apte \& Alahari, 1994). The identity of the other eight polypeptides is unknown.

\section{DISCUSSION}

Based on information mostly obtained from heterotrophs, the major role(s) assigned to $\mathrm{K}^{+}$in bacteria is the maintenance of cellular turgor and intracellular $\mathrm{pH}$. Much less is known about the role of $\mathrm{K}^{+}$in the physiology and metabolism of photoautotrophic and/or diazotrophic bacteria, which have life-styles strikingly different from those of heterotrophs. In particular, the role(s) of $\mathrm{K}^{+}$in the vital processes of photosynthesis and nitrogen fixation, if any, have not been adequately investigated. In the photosynthetic nitrogen-fixing cyanobacterium Anabaena torulosa, $\mathrm{K}^{+}$deficiency caused pleiotropic effects (Table 1).

As in other bacteria, $\mathrm{K}^{+}$appears to have some broadbased general effects on the cellular physiology of Anabaena strains. Involvement of $\mathrm{K}^{+}$in maintenance of $\mathrm{pH}$ and membrane potential was reported earlier in Anabaena strains (Reed et al., 1981). A possible loss of turgor during $\mathrm{K}^{+}$starvation is suggested by the significantly decreased cell size of A. torulosa filaments under these conditions. Further functions of $\mathrm{K}^{+}$ suggested by the present study include its involvement in cyanobacterial photosynthesis, nitrogen fixation and particularly in regulation of protein synthesis. Whether 
these effects on the major metabolic activities of Anabaena are related to or are independent of the involvement of $\mathrm{K}^{+}$in turgor maintenance is not clear at present.

The cyanobacterial requirement of $\mathrm{K}^{+}$appeared to be distinctly different from that for $\mathrm{Na}^{+}$, reported earlier in Anabaena strains. While $\mathrm{Na}^{+}$was needed in trace amounts $(25 \mu \mathrm{M})$ specifically during diazotrophic growth (Apte $\&$ Thomas, 1980), $\mathrm{K}^{+}$was required as a macronutrient $(5 \mathrm{mM})$ during both nitrogen-fixing and nitrogen-supplemented growth (Fig. 1). $\mathrm{Na}^{+}$deprivation did not influence the synthesis of nitrogenase proteins (Apte \& Thomas, 1984, 1985), while $\mathrm{K}^{+}$deprivation decreased the synthesis of dinitrogenase reductase (Fig. 5). Impairments of photosynthesis caused by $\mathrm{Na}^{+}$ deficiency were indirect effects of nitrogen starvation since they could be reversed by addition of nitrogenous compounds (Apte \& Thomas, 1983). In contrast, $\mathrm{K}^{+}$ deprivation adversely affected photosynthesis, irrespective of the availability/unavailability of combined nitrogen during growth (Table 1$)$. The primary lesions caused by $\mathrm{Na}^{+}$deficiency were reduced transport of inorganic phosphate (Apte \& Thomas, 1985) and bicarbonate (Maeso et al., 1987). The observed multiple effects of $\mathrm{K}^{+}$deficiency make it somewhat difficult to identify the primary target(s) of $\mathrm{K}^{+}$deprivation in $A$. torulosa.

All the defects caused by $\mathrm{K}^{+}$starvation were fully reversed upon supplementation of $\mathrm{K}^{+}$, demonstrating that they derived from $\mathrm{K}^{+}$deficiency. Absence of cell lysis in $\mathrm{K}^{+}$-deficient cultures and the rapid and nearcomplete revival of $\mathrm{K}^{+}$-replete cells suggested that $\mathrm{K}^{+}$ deprivation was not lethal. Reversal of all physiological/biochemical activities and growth occurred even after prolonged $\mathrm{K}^{+}$starvation (Fig. 2), indicating that the effects of $\mathrm{K}^{+}$deprivation were bacteriostatic rather than bactericidal. After readdition of $\mathrm{K}^{+}$, nitrogen fixation recovered concomitantly with photosynthesis and was fully restored within $24 \mathrm{~h}$. Complete recovery of photosynthesis was rather slow, probably because it involved biosynthesis of nitrogenous photosynthetic pigments (chlorophyll $a$, phycocyanin), which in turn depended on the availability of fixed nitrogen.

$\mathrm{K}^{+}$deprivation caused profound alterations, both qualitative and quantitative, in the nature of proteins synthesized. Prominent among the repressed proteins were the dinitrogenase reductase (NifH or Fe-protein) (Fig. 5) and major phycobiliproteins (Fig. 6). The functional significance of other modifications in protein synthesis, especially those induced by $\mathrm{K}^{+}$deprivation (Fig. 6), is not clear at present. One of the induced proteins $(78 \mathrm{kDa})$ appears to belong to a $\mathrm{K}^{+}$-dependent ATPase. In E. coli such a Kdp-ATPase facilitates rapid accumulation of $\mathrm{K}^{+}$aimed at osmotic/turgor adjustments (Epstein, 1992). It seems likely, therefore, that some of the proteins induced by $\mathrm{K}^{+}$deficiency may be involved in procurement of $\mathrm{K}^{+}$and subsequent adaptation of $A$. torulosa to $\mathrm{K}^{+}$starvation.

\section{ACKNOWLEDGEMENTS}

The authors wish to thank Professor Paul Ludden (Department of Biochemistry, University of Wisconsin, Madison, USA) for his generous gift of the antiserum against dinitrogenase reductase, Professor Karl Altendorf (Department of Microbiology, University of Osnabruck, Osnabruck, Germany) for the anti-KdpB antiserum, and Dr N.K. Ramaswamy of this institute for his help in oxygraphic measurements.

\section{REFERENCES}

Altendorf, K. \& Epstein, w. (1993). Kdp-ATPase of Escherichia coli. Cell Physiol Biochem 4, 160-168.

Apte, S. K. \& Alahari, A. (1994). Role of alkali cations $\left(\mathrm{K}^{+}\right.$and $\mathrm{Na}^{+}$) in cyanobacterial nitrogen fixation and adaptation to salinity and osmotic stress. Indian J Biochem Biophys 31, 267--279.

Apte, 5. K. \& Bhagwat, A. A. (1989). Salinity stress-induced proteins in two nitrogen-fixing Anabaena strains differentially tolerant to salt. J Bacteriol 171, 909-915.

Apte, S. K. \& Thomas, J. (1980). Sodium is required for nitrogenase activity in cyanobacteria. Curr Microbiol 3, 291-293.

Apte, S. K. \& Thomas, J. (1983). Impairment of photosynthesis by sodium deficiency and its relationship to nitrogen fixation in the cyanobacterium Anabaena torulosa. FEMS Microbiol Lett 16, 153-157.

Apte, S. K. \& Thomas, J. (1984). Effect of sodium on nitrogen fixation in Anabaena torulosa and Plectonema boryanum.J Gen Microbiol 130, 1161-1168.

Apte, S. K. \& Thomas, J. (1985). Effect of sodium on membrane potential, uptake of phosphate, nucleoside phosphate pool and synthesis and expression of nitrogenase in Anabaena torulosa. Indian J Exp Biol 23, 518-522.

Apte, S. K., Reddy, B. R. \& Thomas, J. (1987). Relationship between sodium influx and salt tolerance of nitrogen-fixing cyanobacteria. Appl Environ Microbiol 53, 1934-1939.

Bhagwat, A. A. \& Apte, S. K. (1989). Comparative analysis of proteins induced by heat shock, salinity and osmotic stress in the nitrogen-fixing cyanobacterium Anabaena sp. strain L-31. I Bacteriol 171, 5187-5189.

Booth, I. R. (1985). Regulation of cytoplasmic $\mathrm{pH}$ in bacteria. Microbiol Rev 49, 359-378.

Castenholz, R. W. (1988). Culturing of cyanobacteria. Methods Enzymol 167, 68-93.

Csonka, L. N. \& Hanson, A. D. (1991). Prokaryotic osmoregulation: genetics and physiology. Annu Rev Microbiol 45, 569-606.

Epstein, W. (1986). Osmoregulation by potassium transport in Escherichia coli. FEMS Microbiol Rev 39, 73-78.

Epstein, W. (1992). Kdp, a bacterial P-type ATPase whose expression and activity are regulated by turgor pressure. Acta Physiol Scand 146, 193-199.

Epstein, W. \& Schultz, S. G. (1965). Cation transport in Escherichia coli. V. Regulation of cation content. J Gen Physiol 49, 221-234.

Fernandes, T. A., lyer, V. \& Apte, S. K. (1993). Differential effects of salt and osmotic stress on growth and nitrogen fixation in Anabaena sp. strain L-31. Appl Environ Microbiol 59, 899-904.

Giaever, H. M., Styrvold, O. B., Kaasen, I. \& Strom, A. R. (1988). Biochemical and genetic characterization of osmoregulatory trehalose synthesis in Escherichia coli. J Bacteriol 170, 2841-2849.

Harold, F. M. \& Baarda, J. R. (1968). Effects of nigericin and 
monactin on cation permeability of Streptococcus faecalis and metabolic capacities of potassium-depleted cells. J Bacteriol 95, 816-823.

Harold, F. M. \& Kakinuma, Y. (1986). Primary and secondary transport of cations in bacteria. Ann N Y Acad Sci 456, 375-383.

lyer, V., Fernandes, T. A. \& Apte, S. K. (1994). A role for osmotic stress-induced proteins in the osmotolerance of a nitrogen-fixing cyanobacterium, Anabaena sp. strain L-31. J Bacteriol 176, 5868-5870.

Mackinney, G. (1941). Absorption of light by chlorophyll solutions. J Biol Chem 140, 315-322.

Maeso, E. S., Pinas, F. F., Gonzalez, M. G. \& Valiente, E. F. (1987). Sodium requirement for photosynthesis and its relationship with dinitrogen fixation and the external $\mathrm{CO}_{2}$ concentration in cyanobacteria. Plant Physiol 85, 585-587.

Meury, J. \& Kohiyama, M. (1993). Role of heat shock protein DnaK in osmotic adaptation of Escherichia coli. J Bacteriol 173, $4404-4410$.

Miller, D. M., Jones, J. H., Yopp, J. H., Tindall, D. R. \& Schmid, W. D. (1976). Ion metabolism in a halophilic blue-green alga, Aphanothece halophytica. Arch Microbiol 111, 145-149.

Palleros, D. R., Reid, K. L., Shi, L., Welch, W. J. \& Fink, A. L. (1993). ATP-induced protein-Hsp70 complex dissociation requires $\mathrm{K}^{+}$ but not ATP hydrolysis. Nature 365, 664-666.

Prince, W. S. \& Villarejo, M. R. (1990). Osmotic control of proU transcription is mediated through direct action of potassium glutamate on transcription complex. $J$ Biol Chem 265, 17673-17679.

Reed, R. H. \& Stewart, W. D. P. (1981). Characterisation of the transport of potassium ions in the cyanobacterium Anabaena variabilis Kurtz. Eur J Biochem 116, 323-330.

Reed, R. H. \& Stewart, W. D. P. (1985). Evidence for turgor- sensitive $\mathrm{K}^{+}$influx in the cyanobacteria Anabaena variabilis ATCC29413 and Synechococcus PCC6714. Biochim Biophys Acta 812, 155-162.

Reed, R. H., Chudek, J. A., Foster, R. \& Stewart, W. D. P. (1984). Osmotic adjustments in cyanobacteria from hypersaline environments. Arch Microbiol 138, 333-337.

Reed, R. H., Warr, S. R. C., Richardson, D. L., Moore, D. J. \& Stewart, W. D. P. (1985). Multiphasic osmotic adjustments in a euryhaline cyanobacterium. FEMS Microbiol Lett 28, 225-229.

Schrempf, H., Schmidt, O., Kummerlen, R., Hinnah, S., Muller, D., Betzler, M., Steinkamp, T. \& Wagner, R. (1995). A prokaryotic ion channel with two predicted transmembrane segments from Streptomyces lividans. EMBO J 14, 5170-5178.

Stumpe, S., Schlosser, A., Schleyer, M. \& Bakker, E. P. (1996). $\mathrm{K}^{+}$ circulation across the prokaryotic cell membrane: $\mathrm{K}^{+}$uptake systems. In Handbook of Biological Physics, vol. 2, pp. 473-499. Edited by W. N. Konings, H. R. Kaback \& J. S. Lolkema. Amsterdam: Elsevier.

Suelter, C. H. (1970). Enzymes activated by monovalent cations: patterns and predictions for the enzyme-catalysed reactions are explored. Science 168, 789-795.

Whatmore, A. M. \& Reed, R. H. (1990). Determination of turgor pressure in Bacillus subtilis: a possible role for $\mathrm{K}^{+}$in turgor regulation. J Gen Microbiol 136, 2521-2526.

Wolk, C. P. (1973). Physiology and cytological chemistry of bluegreen algae. Bacteriol Rev 37, 32-101.

Wood, N. B. \& Haselkorn, R. (1980). Control of phycobiliprotein proteolysis and heterocyst differentiation in Anabaena. J Bacteriol 141, 1375-1385.

Received 6 November 1997; revised 2 February 1998; accepted 13 February 1998. 